not up till now sufficiently attempted this part of the subject; I hope to do so on a future occasion. Meanwhile the elucidation of the features themselves, the preparation of cross-sections of the submerged cañons, escarpments, and other phenomera, have occupied so much of my time and have been of such absorbing interest that I have thought it better to leave the question of geological age and mode of formation to the future. This part of the subject I hope to deal with when the paper, now nearly written, shall have been brought before one of our scientific societies during the ensuing session.

Edward Hull.

\title{
OBITUARY.
}

\section{PROFESSOR des CloizeauX, Memb. Inst. de France.}

BonN 1817 .

DIED MAY, 1897.

Monsieur Alfred L. O. Des Cloizeaux, the eminent French mineralogist, was a Membre de l'Institut de France and a Foreign Member of the Royal Society. He was Professor of Mineralogy in the Museum of Natural History, Paris, and was elected a Foreign Member of the Geological Society of London in 1884. Sir Warington Smyth, when receiving the Wollaston Medal of that Society on behalf of M. des Cloizeaux, said: "It is more especially in the wide and successful application of Wollaston's invention of the 'Reflecting Goniometer' that Des Cloizeaux has attained so deserved an eminence, following closely upon the steps of Professor Miller, to whom, in his admirable "Manuel," he pays so high a compliment." Des Cloizeanx's first paper was published 54 years ago, and was the beginning of a long series treating of the forms and optical characters of crystals. After being Professor of Mineralogy for eighteen years at the Ecole Normal Superieure, he was appointed to the charge of the minerals at the Musée d'Histoire Naturelle, in which office he remained until he reached the limit of age prescribed by the rules of the French Civil Service. His fame rests upon the thoroughness and accuracy of his systematic investigation of the crystals of minerals, more especially as regards their optical properties. The results are incorporated in his "Manuel de Minéralogie," a standard book of reference. Professor des Cloizeaux died, in the 80 th year of his age, in May, 1897. Monsieur Damour, his friend and co-worker for fifty-three years, writes: "In everything he applied himself to the spread of all that he deemed useful, just, and wise. All those who knew him honoured him and loved him. His name as a savant remains in the history of Mineralogy; he there occupies the most honourable place among the founders of this science, and among those who have contributed to its progress and advancement." 